\title{
THE AGENT ORANGE VETERAN PAYMENT PROGRAM
}

\author{
HaRvey P. BERman* \\ I \\ INTRODUCTION
}

On May 7,1984 , a settlement was reached in a class action brought by Vietnam veterans and members of their families against seven chemical companies for injuries (including disability and death of veterans and birth defects in children of veterans) alleged to have been caused by the veterans' exposure to Agent Orange and other phenoxy herbicides in Vietnam. ${ }^{1}$ Soon after settlement, Aetna learned of the opportunity to participate in a program to pay the settled claims. Before participating in such a program, however, Aetna had to conduct a cost-benefit analysis of its participation. From a positive standpoint, the payment program presented an opportunity for Aetna to do what it does best-process and pay claims-in a new context. Successful administration of such a program could result in new business opportunities in similar mass tort settlement situations. On the other hand, the Agent Orange litigation had aroused strong emotions in the veteran community. There was a danger that association with such a project, particularly in connection with the denial of claims, could create adverse publicity and alienate a significant segment of the insurance-buying public. Moreover, as an insurer, Aetna was concerned about participation in an arrangement where private corporations had assumed the burden for injuries resulting from a governmental function. Finally, Aetna was concerned that operating under the control of the court would reduce the degree of flexibility needed to administer successfully a program different from that of the usual benefit arrangements. Meetings and discussions with various veterans' groups (including Aetna-employed Vietnam veterans) and with the office of the special master of the payment program convinced us, however, that not only was Aetna able to do the job, but that such involvement could lend credibility to the project. With the court providing general guidelines and eligibility

Copyright (c) 1990 by Law and Contemporary Problems

* Counsel, Aetna Life and Casualty Company.

Much of the information upon which this article is based is drawn from my experience as counsel to Aetna Technical Services, Inc., and Aetna Life Insurance Company, the claims administrators for the Agent Orange Veteran Payment Program. These companies will be collectively referred to herein as "Aetna" or the "claims administrator." Since much of this information has never been published and is not the property of Aetna, or is based upon unreported orders or directions of Judge Weinstein, it is simply incapable of being cited according to the usual methods.

1. In re Agent Orange Product Liability Litigation, 597 F Supp 740 (ED NY 1984), modified, 818 F2d 145 (2d Cir 1987). 
criteria, Aetna's job as claims administrator of the Agent Orange Veteran Payment Program was seen as primarily one of filling in the eligibility details and developing the necessary processes.

This article, which focuses almost entirely on Aetna's contract to administer the payments under the settlement, summarizes (1) the litigation and the settlement of that litigation, resulting in the establishment of the Agent Orange claims facility, (2) the makeup and operation of the facility, and (3) some lessons learned by the facility's claims administrator.

\section{II}

\section{The Litigation}

Following settlement of the class action, Judge Jack Weinstein of the United States District Court for the Eastern District of New York appointed Kenneth R. Feinberg as special master to develop a plan for distribution of the settlement funds-expected to be almost $\$ 200$ million after attorneys' fees and expenses. ${ }^{2}$

Judge Weinstein accepted the special master's distribution plan with some modifications on May 28, 1985.3 As modified, the plan provided for a payment program to distribute approximately $\$ 150$ million (subsequently grown to approximately $\$ 170$ million) in cash payments to eligible veterans and families of deceased veterans, and a nonprofit foundation initially funded at $\$ 45$ million to provide services to exposed veterans and their families, particularly veterans' children with birth defects. ${ }^{4}$ Actual distribution could not begin until all appeals were decided. 5 The program was designed to have a ten year life, expiring in 1994, with provision for investment of unpaid funds during that period. 6 A key element of the cash payment plan, extraordinary for a mass tort case, was the provision of awards for nontraumatic total disability or death of a veteran exposed to Agent Orange, without a showing of a causal relationship between the exposure and the health problem. ${ }^{7}$

More than 200 companies-including insurers, third-party administrators, and data processing companies-expressed interest in bidding on the contract to administer the cash payment plan. On June 24, 1986, Special Master Kenneth Feinberg awarded Aetna the contract, ${ }^{8}$ subject to the

2. In re Agent Orange Product Liability Litigation, 611 F Supp 1396, 1402 (ED NY 1985), modified, 818 F2d 179 (2d Cir 1987). For Feinberg's discussion of the mass resolution of the Dalkon Shield claims, see Kenneth R. Feinberg, The Dalkon Shield Claimants Trust, 53 L \& Contemp Probs 79 (Autumn 1990).

3. 611 F Supp at 1400 .

4. Id.

5. Id at 1451; In re Agent Orange Product Liability Litigation, 611 F Supp 1223, 1264 (ED NY 1985).

6. See $611 \mathrm{~F}$ Supp at $1417,1448$.

7. Id at 1402-03. See also In re Agent Orange Product Liability Litigation, 818 F2d 179, 183-84 (2d Cir 1987) (upholding ruling that no causation need be shown).

8. Claims Administration Agreement Among the Agent Orange Fund, Aetna Technical Services, Inc., as Claims Administrator, and Aetna Life Insurance Company (July 8, 1988) ("Claims Administration Agreement"). 
approval of Judge Weinstein and the development of a mutually acceptable agreement. ${ }^{9}$ Separate contracts were awarded for the investment function. ${ }^{10}$

On August 26, 1986, the United States Court of Appeals for the Second Circuit issued a stay of implementation of the distribution plan, pending resolution of an appeal by the Agent Orange Plaintiffs' Management Committee, and ordered Aetna to cease all work on the project. The Plaintiffs' Management Committee argued that the payment plan should compensate only those with injuries linked to dioxin, a substance found in Agent Orange. The committee also opposed the establishment of the nonprofit social services foundation, which was to provide grants and other funding to assist veteran class members and their families. ${ }^{11}$

On April 21, 1987, in nine separate opinions, the Second Circuit affirmed all of the district court judgments, with some modifications. ${ }^{12}$ The court did strike down the nonprofit foundation, however, indicating that the district court should consider selected projects under the control of the court to assist veterans. $^{13}$ The payment program was not affected. ${ }^{14}$

\section{III}

\section{The FACILITY}

The facility through which the settlement was implemented is the Agent Orange Fund ("Fund"), an unincorporated, tax-exempt, charitable organization. Established by court order, the legal basis for the Fund lay in the discretion granted to it by the settlement agreement, the authority provided by Rule 23 of the Federal Rules of Civil Procedure, and the court's inherent equity power. ${ }^{15}$ The Fund includes the monies to be distributed by the payment program, those to be paid for other social services, and those to be paid to trusts in Australia and New Zealand for the benefit of veterans in those countries. The maintenance and administration of these monies is subject to the continuous jurisdiction of the court. ${ }^{16}$

The Fund is managed by court-appointed officers, who are authorized to contract with various organizations for the distribution of funds to veterans and social service programs. Upon the resolution of all appeals, that portion of the settlement funds designated for the payment program was transferred

9. See In re Agent Orange Product Liability Litigation, 689 F Supp 1250, 1266 (ED NY 1988) (approving the appointment of Aetna and the terms of the agreement).

10. Agreements between the Agent Orange Fund and Irving Trust Company, and Brown Brothers Harriman \& Co., as Investment Managers, and Irving Trust Company, as Depository (July $8,1988)$.

11. 818 F2d at $\mathbf{1 8 4 - 8 6}$ (overturning class assistance program).

12. The opinions of these cases are summarized in the first decision, In re Agent Orange Product Liability Litigation, 818 F2d 145, $151-52$ (2d Cir 1987). The remainder of the opinions, all bearing the same name and issued from the Second Circuit on the same date, are as follows: 818 F2d 226; 818 F2d 216; 818 F2d 210;818 F2d 204; 818 F2d 201; 818 F2d 194; 818 F2d 187; 818 F2d 179.

13. 818 F2d $179,184-86$.

14. Id at 183-84.

15. 611 F Supp at 1402-03.

16. Id at $1429-30$. 
from escrow to the Fund. Now being managed by investment managers, the Fund will make initial payments to each veteran or survivor once initial eligibility is certified, and yearly disability payments for each year the veteran's eligibility continues during the life of the program. ${ }^{17}$ If investment earnings are higher than expected, or claims are lower than expected, amounts payable in subsequent years may be increased, both for deaths and newly-arising disabilities, and for existing disabilities. ${ }^{18}$ No assets of the Fund may revert to the chemical company defendants or be used for non-charitable purposes. ${ }^{19}$

Officers of the Fund, which is headquartered in Brooklyn, New York, consist of a president (Special Master Feinberg) and a vice president (who is the Special Master for Investment Policy). ${ }^{20}$ A program manager for the payment program has been designated, and an advisory board has been created to advise the court and the Fund on the implementation of the payment program.

Unless the court determines otherwise, the Fund will be dissolved by court order in 2009 at the termination of the settlement agreement, ${ }^{21}$ or when all funds have been distributed, whichever is earlier. Ten million dollars of the settlement funds will be held by the court until dissolution to indemnify the defendants against state court judgments. ${ }^{22}$

Compensation of the claims administrator by the Fund is based upon agreed-upon hourly or daily rates for work performed in designated labor categories, and the cost of certain other services and facilities provided. Compensation of the investment managers is based upon agreed-upon percentages of Fund assets under management.

\section{IV}

\section{The Claims Administration Agreement}

The Claims Administration Agreement governs the relationship between the Fund and Aetna and, among other things, describes the duties and responsibilities of the claims administrator. ${ }^{23}$ The duties of the claims administrator include document development, maintenance of veteran mailing lists and of the claim-file database, veteran information services, liaison with other consultants, claim processing (including application of eligibility criteria and adherence to performance standards), banking services, reports, quality control and audit of claims administration services, testing and staff training, and actuarial services involving analysis of claims

17. See id at $1418,1448-49$.

18. See, for example, id at 1421-22.

19. See id at 1403 (discussing the cy pres doctrine).

20. The special master for investment policy is Attorney Richard J. Davis of Weil, Gotshal \& Manges, New York.

21. Id at $1437 ; 689 \mathrm{~F}$ Supp at 1266 .

22. 597 F Supp at 864-65.

23. See generally Claims Administration Agreement at $\S \S 2.01-2.02$ (cited in note 9); see also 611 F Supp at 1410-12. 
experience. The agreement also specifies such terms as the location of operations, limits on subcontracting, prevention of conflicts of interest, changes in functions and responsibilities, and the degree of care expected of the claims administrator. ${ }^{24}$

The role of the special master and the legal relationships between the special master, the court and the claims administrator also are set forth in the agreement. ${ }^{25}$ The special master administers the Fund "under the supervision and direction of the [c]ourt and with the advice and assistance of the [a]dvisory [b]oard."26 The special master, the advisory board, other representatives of the Fund, and the court are responsible for all general communication with the public. ${ }^{27}$ With certain limited exceptions, the claims administrator is prohibited from communicating directly with members of the public about the Fund. ${ }^{28}$ Finally, the special master, as well as the other representatives of the Fund, is not personally liable for any of his official actions or for any breach of the Claims Administration Agreement itself. ${ }^{29}$ The claims administrator may look only to the "Fund (or its successor organization) and its assets . . . for payment under [the Claims Administration] Agreement or for relief in case of breach of [the] Agreement."'30

Besides defining the basis for compensation (including adjustments) and the terms of payment, the agreement also provides for handling compensation if the agreement is terminated. ${ }^{31}$ The agreement also mandates the maintenance of minimum levels of liability and other insurance (including bonding) by the claims administrator and indemnifies both the Fund and the claims administrator against loss resulting from a breach of duty by the other party. ${ }^{32}$

Under the agreement, disputes between the parties are to be submitted to binding arbitration if they cannot be resolved by negotiation. ${ }^{33}$ All proceedings related to the agreement are subject to the jurisdiction of the United States District Court for the Eastern District of New York, and the agreement is governed by the laws of New York. ${ }^{34}$ The special master may bypass negotiation and arbitration, however, and apply directly to the court for specific performance or for any other equitable relief necessary to protect the interests of the class members. ${ }^{35}$

24. Claims Administration Agreement at $\$ \S 2.03-2.08$ (cited in note 9).

25. See generally id at $\S 3$.

26. Id at $\S 3.01$. The advisory board is composed of five court-appointed Vietnam veterans who advise the court and the special master on implementation of the program. Id at $\S 1$ (definitions).

27. Id at $\$ 3.02$.

28. Id.

29. Id at $\$ 3.05$.

30. Id.

31. Id at Attachment $C$.

32. Id at $\$ 7$ (providing insurance coverage for bodily injury, property damage, automobile liability, and workers' compensation).

33. Id at $\S 12.01$.

34. Id at $\S 12.02$.

35. Id at $\S 12.01$. 


\section{The Payment Program}

As indicated above, the payment program is unique in that the eligibility process does not involve establishment of the normal tort elements: causation, fault, and proof of damages. Rather, the process is designed to provide as much relief as possible to those individuals most in need of assistance who can satisfy certain threshold criteria. Thus the victims avoid the need to establish a violation of a duty owed to them and a causal link to their injuries; in return, they give up the right to collect in proportion to their specific losses. This situation is analogous to that under a first-party insurance policy that offers scheduled benefits for certain types of losses such as loss of a limb or accidental death.

Eligibility for payments requires a showing that (1) the veteran was exposed to Agent Orange in or near Vietnam at any time from 1961 through 1971 , (2) the veteran, or the veteran's child, suffers from a long-term total disability or has died, and (3) the death or disability arose principally from causes other than trauma, accident, or self-inflicted injury. ${ }^{36}$

\section{A. Exposure}

The Fund has contracted with exposure consultants ${ }^{37}$ to develop a methodology for evaluating exposure to Agent Orange as a part of the claim process. A questionnaire was designed to elicit information about the dates and locations of the veteran's service in Vietnam and whether the veteran had duties involving the handling or application of Agent Orange. ${ }^{38}$ After the questionnaires are completed, the consultants analyze the data under a computerized process that also considers authenticated sources of information about military unit locations in Vietnam and records of herbicide dissemination. Finally, exposure is determined by certain criteria, such as actual handling or application of Agent Orange, or presence in a sprayed area within temporal and geographic limits established by the court. Under this methodology, there are no degrees of exposure-the veteran either has been exposed or has not. After analysis of the initial batch of processed claims, the minimum exposure threshold may be adjusted to maintain claim incidence expectations.

\section{B. Total Disability and Death}

Disability will be determined in accordance with the definition in the Social Security Act, ${ }^{39}$ and veterans who are receiving Social Security disability

36. See 689 F Supp at 1290,1293 App B (summarizing the conditions for recovery in the application materials).

37. Id at 1265. Doctors Jeanne Stellman and Steven Stellman are the exposure consultants. Id.

38. The methodology is discussed at $689 \mathrm{~F}$ Supp at 1263-66; 611 F Supp at 1415-17.

39. 42 USC $\$ 301-1397 \mathrm{f}$ (1983). Disability is defined as the "inability to engage in any substantial gainful activity by reason of any medically determinable physical or mental impairment which can be expected to result in death or which has lasted or can be expected to last for a 
benefits will be presumed to be disabled for purposes of the payment program. ${ }^{40}$ For veterans who are not receiving Social Security benefits, the claims administrator will apply the Social Security definition with its own claim settlement practices, giving the benefit of the doubt to the claimant in questionable situations. Disability will be deemed to commence on the date of onset determined by the Social Security Administration, if such a finding has been made. Otherwise, disability is presumed to have commenced on the later of the first day of the program (January 1, 1985) or the date of filing a claim. The veteran may overcome this presumption, however, with a showing of "evidence clearly demonstrating the date of onset." 41 Disability will be deemed to terminate when the veteran dies or recovers from the disability. ${ }^{42}$

Under the original distribution plan, surviving spouses or dependent children of a deceased veteran who met the general eligibility criteria described above are eligible for one-time survivor payments. Spouses must have been lawfully married to the veteran at the time of his death. Surviving children (including stepchildren, adopted children, and foster children living in the veteran's home) under age nineteen or full-time students at the time of the veteran's death are eligible, but only if there is no surviving spouse. All eligible surviving children will share the payment equally. ${ }^{43}$ In November, 1989, the court expanded the definition of eligible survivors to include, in order, the veteran's parents, adult children, and siblings if there is no spouse or child meeting the original definition. ${ }^{44}$

\section{Excluded Causes}

Deaths or disabilities predominantly caused by traumatic, accidental, or self-inflicted injury are not eligible for payment. Thus, excluded injuries would include war wounds, auto accidents, falls, suicides or attempted suicides, intentional drug overdoses, and gunshot wounds. ${ }^{45}$ These types of claims are most probably unrelated to Agent Orange exposure and are relatively easy to define and administer.

\section{The Claim Process}

To be considered timely, claims for disabilities or death originally had to be filed by January $1,1989 .{ }^{46}$ However, the court has now removed all timely

continuous period of not less than 12 months ..." Id at $\S 423(d)(1)(A)$. See also 611 F Supp at 1412-13.

40. See generally $611 \mathrm{~F}$ Supp at 1412-13.

41. Id at 1419-20.

42. Id at 1420 .

43. $680 \mathrm{~F}$ Supp at 1293 App B (summarizing the criteria for survivor payments in the application materials).

44. Second Annual Report of the Special Master on the Distribution of the Agent Orange Settlement Fund 9 (September 27, 1990) ("Second Annual Report").

45. See, for example, 611 F Supp at 1412. This does not exclude long-term drug or alcohol dependency, however.

46. $689 \mathrm{~F}$ supp at $1262-63$. 
filing requirements. ${ }^{47}$ The current application for payment is a comprehensive yet easily readable form with complete instructions for furnishing all necessary medical, exposure, and other information. ${ }^{48}$ The form also contains a program description and is available in Spanish. The process is designed to obviate the need for counsel to assist the claimant. Based upon data collected on potential claimants, 295,000 preliminary letters were mailed to veterans with information about the program. The claims administrator has received 115,000 requests for claim kits, that is, applications for payments, and 48,000 completed claims, both of which are consistent with expectations. ${ }^{49}$

The claims administrator acknowledges completed applications, reviews them for completeness, and requests additional information as necessary. The claims administrator then determines whether the claimant meets the eligibility criteria described above, and notifies the claimant of denial or approval of the application. ${ }^{50}$ The claims administrator also provides a tollfree number for questions about the program or particular claims. ${ }^{51}$

Claims denied by the claims administrator must contain the reason for denial and are subject to appeal to a special master for appeals appointed by the court. ${ }^{52}$ Use of counsel by the claimant at this point would not be unexpected, based upon experience with other insurance arrangements, although such use has not proven to be common.

\section{E. The Payment Process}

The claims administrator paid the first death claims in February of 1989 and the first disability claims in March of 1989. Initial payments have been made on a weekly basis after approval by the program manager. Before such dates, a statement is sent to the investment managers specifying the total amount to be paid.53 The claims administrator pays claims by drafts drawn on a payment bank. Upon presentment, the payment bank will inspect and accept the drafts and advise a depository bank to make sufficient funds available to the payment bank to cover the drafts.

\section{F. Payment Amounts}

Payment levels will depend on the total number of disabled or deceased veterans for whom claims are submitted, and the number of claimants meeting exposure and other eligibility requirements. The estimated maximum award for disability was originally estimated to be about $\$ 12,800$

47. Second Annual Report at 8 (cited in note 45).

48. This form is reproduced at $689 \mathrm{~F}$ Supp at 1287-1318 App B.

49. Second Annual Report at 14,16 (cited in note 45).

50. See, for example, $689 \mathrm{~F}$ Supp at 1266-68.

51. Since the program's inception, the claims administrator has responded to more than 395,000 telephone calls. Second Annual Report at 13 (cited in note 45).

52. As of August 31, 1990, 4,672 appeal decisions had been rendered; 3,329 affirming the decision of the claims administrator. Id at 25.

53. $689 \mathrm{~F}$ Supp at 1279. 
over the life of the program, which, as noted above, is expected to terminate December 31, 1994.54 Disability awards will be payable in annual installments, and individual awards will vary according to the age of the veteran and the duration of the disability. Lower payments are made to older veterans and for shorter disabilities. ${ }^{55}$ No credit is given for any year of disability after a veteran's sixtieth birthday. ${ }^{56}$ In December of 1989 , the court ordered one-time, "bonus" payments to be made to all veterans receiving disability benefits under the program before November 15, 1989.57

Death benefits are paid in a lump sum, with the maximum benefit originally estimated at approximately $\$ 3400$. Survivors of veterans who died before the program commenced receive the maximum benefit; awards for other survivors are based on the number of years remaining in the program at the time of the veteran's death. No payment is made for death occurring after the age of sixty. ${ }^{58}$

Payments after the first year of the program are adjusted upward or downward based upon claim incidence in the first year, changes in projected investment earnings, and other relevant factors. Such adjustments will be made periodically throughout the life of the program. The objective of such adjustments, of course, is to provide for the maximum payout possible while maintaining funds to support payments over the life of the program. The claims administrator will provide the actuarial services necessary for such adjustments under the Claims Administration Agreement.

\section{VI}

\section{Assessment of the Payment Program}

\section{A. Strengths and Assets}

There are several strengths and assets of the payment program that should enable it to achieve its objectives cost-effectively. Probably the most important is the structure of the settlement plan itself, which avoids the need to relitigate the liability and damage issues in each claim. Eligibility for awards will be determined, to the maximum extent possible, by reference to objective criteria with minimal exercise of judgment. ${ }^{59}$ The effect of this structure is to maximize benefits and minimize expenses.

As indicated above, determining eligibility by a process that primarily uses objective factors has enabled the claims administrator to reduce the cost of the claim process by taking maximum advantage of sophisticated computer

54. Id at 1257-58. Because of interest earned during the appeals, and an increase in the funding of the payment program, Judge Weinstein noted that this figure would probably be increased. Id.

55. Id at 1258 .

56. Id; 611 F Supp at 1418-20.

57. Second Annual Report at 11 (cited in note 45).

58. $611 \mathrm{~F}$ Supp at $1420-21$; see also $689 \mathrm{~F}$ Supp at 1258 .

59. One exception is the determination of disability where the veteran is not receiving Social Security disability benefits, since the claims administrator will not be able to "piggyback" on the Social Security determination. 
systems. ${ }^{60}$ These systems also should contribute to more effective reporting and analysis of the claim experience, which supports necessary adjustments in the program and otherwise facilitates the court's and the special master's oversight functions.

Another strength is the communication system that is an integral part of the program. The preliminary letters to veterans were the first step in that process, providing a clear written description of the program and the claim process. The claim kits provide additional information. Through the toll-free telephone system, the claims administrator can answer questions and provide information about the claim process, the settlement, and counseling resources available to the veterans. More than 395,000 calls have been handled through this system, and the special needs of particular groups, including Spanishspeaking and institutionalized veterans, have been taken into account.

\section{B. Weaknesses and Problems}

One problem that arose after the project was well underway was the disruption caused by the Second Circuit's stay of implementation of the plan in August 1986. Obviously, this was something over which neither Aetna nor the district court had any control. At that point, Aetna had expended significant amounts of money and time to hire and train personnel and purchase equipment, and had reserved space within Aetna facilities to operate the project. During the almost two-year hiatus between the entry of the stay and the Supreme Court's denial of certiorari, it was impossible to retain all of these resources, and it was necessary to start over in some respects in June of 1988. By working as a consultant for the Fund during a portion of the hiatus, however, Aetna was able to continue development of some of the basic tools needed to process claims so that a minimum of additional time was lost from the original implementation schedule.

One operational weakness, at least from the claims administrator's standpoint, is that all of the functions and resources necessary to implement the payment program are not concentrated in one entity. Among other things, development of the exposure criteria and management of general information concerning the program are not within the control of the claims administrator, even though such functions may directly impact on the quality of its work. While this has not been an overwhelming problem, it has led to some disruptions in work schedules. For example, publication of news articles regarding the payment program has triggered more calls to the claims administrator than it was equipped to handle, thus putting a strain on the communication system. Similarly, reliance on the exposure consultants to finalize the recommended criteria caused some delay in the implementation of the claim process.

60. For a discussion of computerizing mass tort claims resolution facilities, see Thomas Florence \& Judith Gurney, The Computerization of Mass Tort Settlement Facilities, 53 L \& Contemp Probs 189 (Autumn 1990). 
While it might be inappropriate to characterize it as a weakness, a program such as the Agent Orange payment program that is under the control and supervision of a court may at times experience a conflict between the legal, result-oriented operations and concerns of the court, and the business, process-oriented operations and concerns of a claims administrator. In other words, the court may be accustomed to taking months to consider a decision and then issuing an order with the expectation that it will be immediately followed. A business organization, despite (and sometimes because of) its computer resources and structure, cannot always react immediately to a change in the operation of the program, at least not without substantial disruption. This type of conflict can be minimized, however, if both the court and the contractors with whom it deals are cognizant of, and consider the effect of their actions on, the needs and functions of the others.

\section{Changes and Recommendations}

In planning for future claims resolution facilities of this type, the Agent Orange Veteran Payment Program can well be looked upon as a valuable learning experience. The lessons learned suggest that future controlling organizations should take certain steps to ensure their success. The controlling organization should determine eligibility for payment on objective factors to the maximum extent possible to avoid litigation of the issues of causation and damages, and to take advantage of the cost savings associated with computerized claim systems. The organization also should concentrate control of the claim process, and the external factors directly affecting that process, in the claims administrator to the maximum extent possible, subject to appropriate oversight by the court. If that cannot be done, the controlling organization should take steps to integrate the operation of all functions to achieve synergy and avoid disruption in the operation of one function by another. Finally, the organization should structure the claim process to avoid a "crush" of claims at the beginning of the program to spread the claim processing burden over a reasonable period.

With regard to the unavoidable period of uncertainty between the date the trial court approves the distribution plan and the date all appeals are exhausted, the organization selected as claims administrator should focus its energies on perfecting the payment system, anticipating different levels of demand from those originally projected, and, in general, working out the "bugs" in the program. Resources needed for implementation should be planned so they can be called upon quickly when needed without incurring expense to retain them prematurely.

\section{VII}

\section{Conclusion}

There were some operational problems in the first year of the Agent Orange Veteran Payment Program that led to slower distribution of fund assets than expected. These problems have been overcome, however, and, as 
of August 31, 1990, the program had distributed $\$ 68.1$ million in cash payments to over 21,000 individual Vietnam veterans and survivors of deceased veterans. ${ }^{61}$ The claims administrator continues to receive approximately 200 new applications per week; it is expected that the claim process will operate smoothly and efficiently throughout the remainder of the program. ${ }^{62}$

61. Second Annual Report at 5 (cited in note 45).

62. Id at 30 . 